\title{
THE CARTOONS AN ACTIVE METHOD OF TEACHING FURNITURE STYLING TO STUDENTS AND CHILDREN
}

\author{
Cristina-Maria Povian \\ Associate Professor, PhD Architect, "Politehnica" University Timișoara, Faculty of Architecture and \\ Urbanism, Center for Research and Sustainable Development, ROMANIA, \\ cristina.povian@yahoo.com
}

\begin{abstract}
The images are used as a teaching aid and as interactive teaching methods for both children and students. In the past, the comic strips played a role in creating an architectural image in the minds of children, representing the starting point in the interpretation of the built space. In the present there were replaced by animated movies whose influence started to be even bigger on the children development, once the time spent in front of the TV has increased.

The article presents first the main statistical data regarding the influence of the television and media on children and teenagers development, and the evolution of their main options for spending their free time, taking into consideration the technology development and their access to it.

In the second part there are presented studies of how architecture and design were integrated in cartoons or movies, being a source of inspiration but also promoting themselves all over the world. One of the most famous examples is the Neuschwanstein Castle in Germany built by King Ludwig II of Bavaria in the 1800s, which has been a source of inspiration for Walt Disney in the process of designing his logo and in his cartoons such as the Sleeping Beauty. Thus this it is internationally recognized due to its architectural value. Architecturally representative buildings, but also pieces of furniture or design objects were included in the "Mickey Mouse" comic strip by American cartoonist Arthur Floyd Gottfredson.

In the last part of the paper there are presented the premises, the development and the results of a workshop realized during a summer school in the rural areas of Timiș County, Romania which had as main theme to teach children architecture and design, with the help of university students. The workshop was organized by The Faculty of Architecture and Urbanism, Politehnica Timișoara, in the villages of Timiș County, Romania. At the workshop participated almost 100 children and the material for the workshop was created with the help of the students involved in the entire process.

Based on the premise that images convey more than words, making information easier to assimilate, this article aim to present a case study on how certain pieces of furniture that are significant to interior architecture can be easier to be presented to university students and children through alternative methods of teaching. For students by carrying out projects in the form of comics which illustrates different stories in which those pieces of furniture are integrated; these representing also the teaching material for the workshop, and for children by using these comics in the learning process.
\end{abstract}

Keywords: active learning, alternative methods of teaching, furniture styling, architecture, interior design, architecture history, cartoons, comic strip. 


\section{INTRODUCTION}

A special attention was given to the influence of media on children development, especially in 2020 when a large part of the educational activities were moved online and the time spent by children in front of the computers increased considerable. The American Academy of Pediatrics (AAP) assert that "Children are influenced by media: they learn by observing, imitating, and making behaviors their own" (AAP, 2001, p.1224). This subject concerns not only parents but also educators, teachers, health care professionals, psychologists and politicians.

\subsection{The role of media and television in children educations and their development}

The role of media and television it can be noticed not only in children's education and development but also in young people and adult's development and continuous education. According to a survey realized between 2008 and 2015 in 15 European countries, on persons with the age between 20 and 74 years old, shows that time spent by adults on screen-related activities as: watching TV, playing computer games, using other electronically gadgets outside work ranges from 3 hours and 17 minutes in Belgium to 2 hours and 18 minutes in Italy. We don't have datas from 2015 to 2020, where the year 2020 is a very important year to be analyzed from this point of view because: children, young people and adults were constrained to spend long periods of time indoor.(Eurostat, 2018)

The influence of media on children's development was easy to be noticed with the appearance of new and more diverse means of communications which were available to the young audience. Many beneficial effects can be enounced like the following: easier access to information, opportunities to be informed about social issues, access to arts and entertainment, learning using alternative methods like games or watching documentaries. (Blackwell Clark).

Children's media started in the early twentieth century with: newspapers, radio shows dedicated to children and movies but with limited timing access. Starting with 1940s the media dedicated to children grown and included: comic books, children's magazines, television, recorded music and storytelling, videotapes, electronic games and the internet. Commercial television made its debut in 1941 and one of the most important events, who represent a positive media influence on children education and development, was the appearance of educational programming offered primarily on public television stations. (Blackwell Clark)

An important television production company was founded in 1968 by Joan Ganz Cooney, Lloyd Morrisett, Gerald Lesser and others named Children's Television Workshop and was designed to create educational programmes which combine learning with entertainment as alternative teaching methods for preschool age children. The programmes produced by Children's Television Workshop: Sesame Street, The Best of Families, The Electric Company, etc, were happily received with very well results and represented a positive influence for other televisions from other countries to develop similar examples. (Hustn \& Donnerstein \& Fairchild \& Feshbach \& Katz \& Murray \& Rubinstein \& Wilcox \& Zuckerman, 1992).

A spectacular development of Internet use in American's homes and schools developed between 1980 and 1990, which expanded media influence on children with a new interactive media element. The Internet revolutionized the computer and communication system, it represents a fantastic mechanism which permits access to information and has the ability to create interaction between people worldwide.

In May 2010, the European Commission adopted a strategy designed to encourage a flourishing digital economy by 2020- "A Digital Agenda for Europe (COM (2010) 245 final)". The main purpose was to maximize the benefits of the digital technology in all sections of society: education, health, economy, etc. Nowadays, in 2020, we can see how information and communication technologies (ICT) are present in people's everyday activities: at the workplace, in the educational system, in administration, in the financial system and also as a way to socialize. According to Eurostat's statistics we can see that comparing to 2010 when only $55 \%$ of households with dependent children had access to the internet, in 2019 the percentage raised to $90 \%$. (Eurostat, 2020)

Children use the information and communication technologies from a very young age, it is common to see young children using mobile phones and tablets even before they start to read or even speak correctly. The ICT skills were also used to support the educational process in subjects as mathematics and foreign languages but in 2020 with the homeschooling it became a must and a very important problem for children in need where the absence of technology deprived them of education. (Eurostat, 2020) 


\subsection{The Presence of Architecture, Iconic Pieces of Furniture in Movies, Cartoons and Comic Strips}

Iconic buildings or famous pieces of furniture represented a source of inspiration for artists who created comic strips, cartoons or movies. The reinterpretation of different famous architectural or artistically objects in media elements can be considered an alternative teaching method for children. From data presented above results that children and young people are one of the most important category of media consumers. The Neuschwanstein Castel in Germany became even more famous, for this age category, because it was the source of inspiration for Walt Disney company logo, a company who became, not only by children, worldwide known.

The insertion of famous architectural pieces it's a practice frequently used not only in cartoons or movies but also in comic strips. In the "Mickey Mouse" comic strip realized by the American cartoonist Arthur Floyd Gottfredson we can discover many examples: from iconic public spaces to famous pieces of furniture or design objects. All this elements are included very naturally in the story presented, appealing to children's visual memory to learn all this elements in an entertaining way, not even noticing that they are familiarized with famous pieces of architecture, arts and design. Floyd Gottfredson was hired at Walt Disney Productions in 1930 and it is best known for his work on "Mickey Mouse comic strip". In Figure 1 we can see examples of how architecture, famous pieces of furniture and design objects are included in the story of the comic strip by Gottfredson. (Delbene Guidoni, 2019)
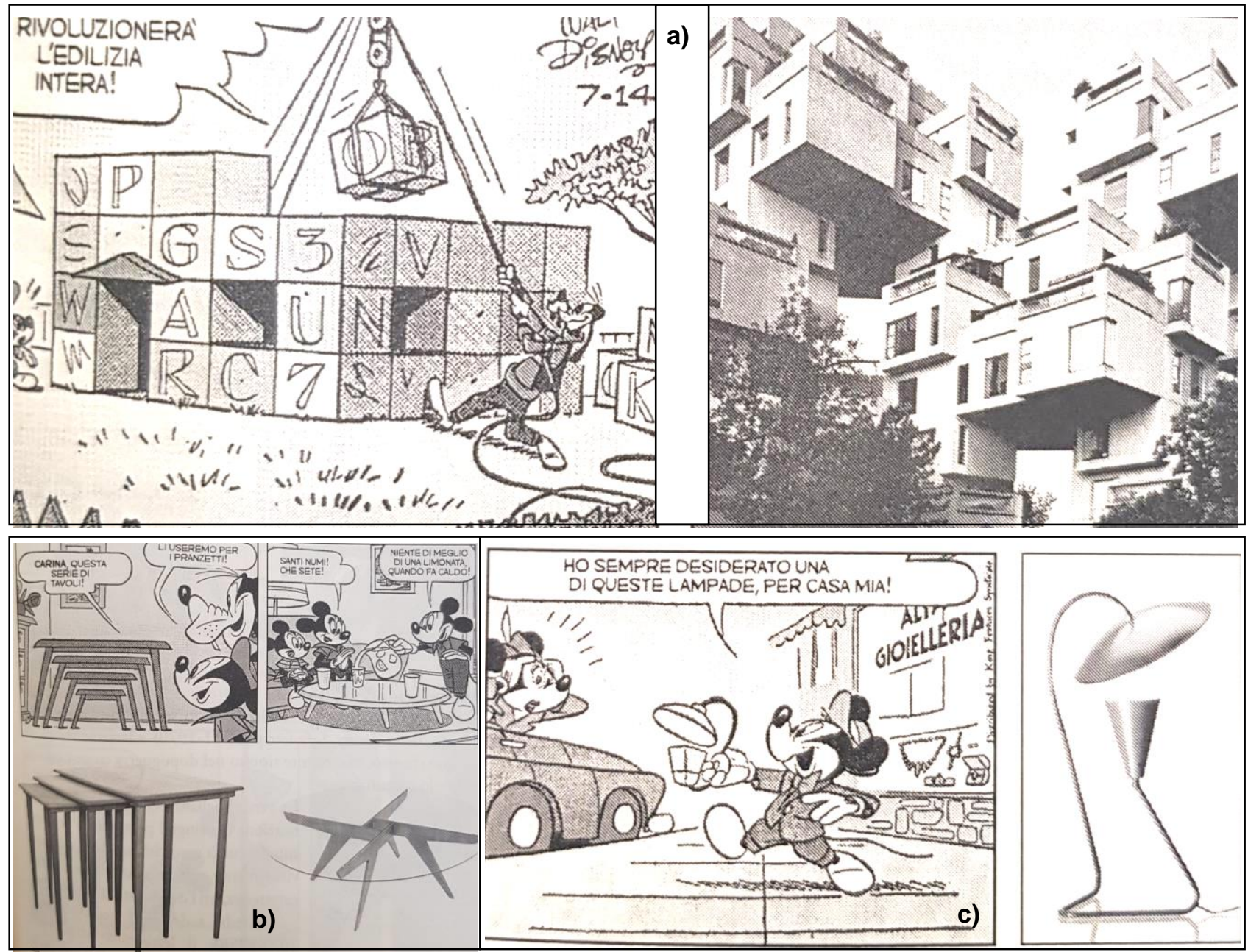

Fig. 1.The presence of iconic buildings, furniture and design onjects in the comic strip "Mickey Mouse" in order to be easy to remember by children; a) Goofy wants to build a prefabricated house using the Lego Technology, strip 21-5-1959 (Delbene Guidoni, 2019, p. 205); b)Tables of Danish Design-1950 and the coffee table designed by Gio Ponti (Delbene Guidoni, 2019, p. 229); c) The lamp designed by M. Eisler and

S. Aczel for llum 1959 (Delbene Guidoni, p.196) 


\section{METHODOLOGY}

Numerous books, articles and publications have gathered, analyzed and systemized information regarding the history of architecture, the main characteristics of interior design styles, the furniture styling and ornamentation; in order to be easier to be assimilate by students from the faculties of Architecture, Arts or Interior Design. (Bucătaru, 1991; Dumitrescu \& Povian \& Milincu \& Tudoran, 2018)

The connection of the development of architecture and interior design with the historical and geographical context increases the amount of information which must be taught. (Bussagli, 2005) The concept of using alternative methods of teaching in order to improve the learning process for students and the quality of learning in a rational way by replacing the traditional methods which rely on "teaching by telling" with other alternatives methods which involves student in different educational workshops or activities. The aim of this article is to present how the alternative methods of teaching used: the method of learning by reinterpreting in drawing and learning by teaching during the summer practical work; have improved the learning process of the courses: "History of Architecture" and "Interior Design Stylistics".

\subsection{Premises and Assumptions}

In the last years many researches were developed in order to help students to learn more effectively. Active learning approaches are often used with children by involving them in different educational activities or workshops. (Povian, 2019)

The aim of this article is to present the results obtained by continuing the research presented in the article "Alternative Methods of Teaching Interior Design Stylistics", presented to the 2019 INTCESS Conference. (Povian, 2020) If in the previous article, mentioned above, the main purpose was to present alternative teaching methods for students, in this article we aim to sediment the information acquired during classes and seminars followed during the academic year and analyze how this process can be developed using active learning approaches that involve both students and children.

In the study presented in this article students are challenged to structure better the information and to create support material for teaching children architecture and stylistics during summer workshops or educational activities. In this way we apply the definition of active learning: „Instructional activities involving students in doing things and thinking about what they are doing". (Bonwell, 1991)

\subsection{Subjects and methods}

At the Faulty of Architecture and Urbanism, Specialization "Furniture and Interior Design", during the second semester of the first year of study about 30-40 students had to attend a 2 hours course of "History of Architecture" and during the first semester of the second year of study a 2 hours course and one hour seminar of "Stylistics" for 14 weeks. At the end of the first and second year of study during 2 weeks they have to engage in activities related to interior design in a company or to realize site surveys or other specific activities in order to link the didactic activity with the real practical activity.

The case study which is presented below represents the structure of the summer practical work dedicated to create material for the "Little Architects Workshops". The summer practical work was organized so students to deepen the information acquired during the $1^{\text {st }}$ and $2^{\text {nd }}$ year of study on the following subjects: "History of Architecture" and "Interior Design Stylistics". All the activities were designed to be creative, interactive and rational in order to use the material obtain as alternative educational methods during the architectural educational workshops dedicated to children from Timiș County villages, organized by Politehnica Timișoara and the Association "AlternativEd Lugoj" during the summer schools.

\subsection{Case Study on the Summer Practical Work- Little Architects Workshops}

The courses are structured mainly on discussions on pictures representing pieces of furniture or examples of interior design representative for each period presented. The alternative methods of teaching from the seminar of "Stylistics" were the subject of another article. (Povian, 2020)

The aim of the theme of this summer practical work was to determine students, even if the evaluation process ended, to continue the learning process in an interactive way and feeling that there work is going to be useful in the process of teaching architecture, art and stylistics to children. There are used three alternative methods of learning: learning with media support; learning by drawing and reinterpretation; and learning by teaching children using also support material designed by them as alternative method. All this process determines the students to think about what they study and create activities in order to identify how it can be easier to transfer the information to children. 
The summer practical work was structured in three parts. In the first part they had to search for examples of iconic buildings, pieces of furniture and design objects in cartoons, movies and comic strips. They had to make a documentation related to the object identified and the connection with the story of the cartoon $/ \mathrm{movie}$ or comic strip. In the second part they had to choose 5 architectural pieces (Figure 3. a1.,b1.c1.) and 5 interior design pieces (Figure 2. a1.,b1.c1.), to analyze them, and to reinterpret them by drawing (Figure 2 and Figure 3. a1.,b1.c1.), creating a comic strip which can help children to learn about the architectural or stylistic features of the object in a fun and easy way. The third part was to present the information to children during the "Little Architects workshop" during the summer schools "The Non-formal Comes to the Village".

For more than ten years the nongovernmental association "Alternativ Education Lugoj" organizes summer schools for children in Timiș County, Romania. During these years approximately 350 children between 5 and 12 years old participated in different educational workshops and more than 50 volunteers from which 15 were from "Politehnica University Timișoara" the Faculty of Architecture and Urban Planning.

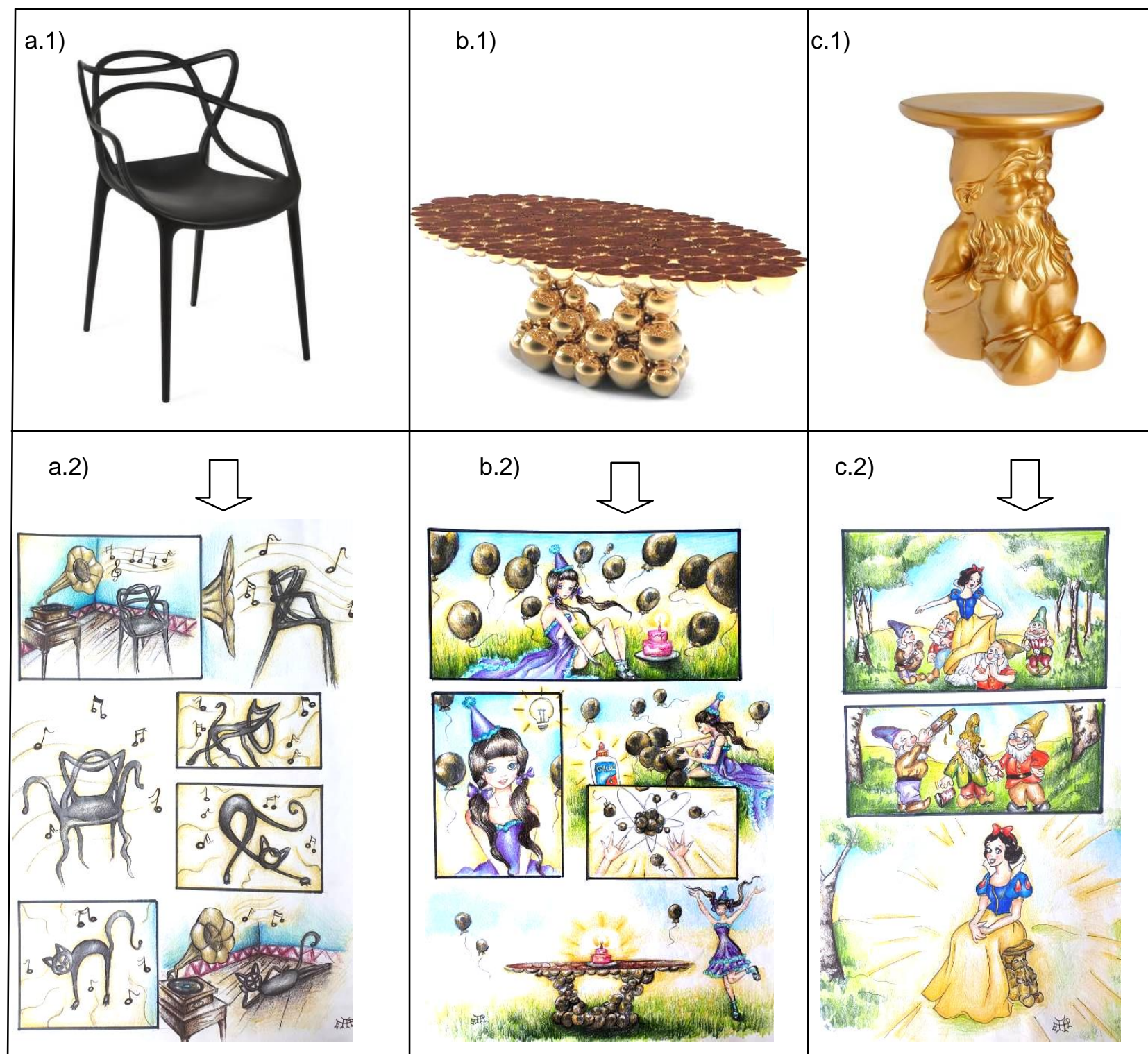

Fig. 2. Worksheets representing three iconic pieces of furniture and their reinterpretation in order to be easy to remember by children; a) Kartell Masters by Philippe Starck chair; b) Newton Dining Table by Boca do Lobo; c) Kartell Gnomes, Napoleon, by Philippe Starck; Online source: a) https://www.diiiz.com/en/designchairs/2510-chair-masters-plastic.html; b) www.bocadolobo.com;

c)https://www.smow.com/en/products/seating/stools/gnomes-napoleon-gold.html; a2),b2),c2) Drawings realized by Andrei Popescu, student at Politehnica University, Faculty of Architecture and Urban Planning,

Furniture and Interior Design Specialization, 2019. 


\section{RESULTS AND DISCUSSIONS}

The theme of the summer practical work in the first part determines student to verify their knowledge related to history of architecture and stylistic by being able to identify different iconic pieces of architecture or interior design in media. They found examples like Flatiron Building or National Library from New-York in Spider Man comic strip from Marvel, the Opera building from Sydney in the animation cartoon "Finding Nemo", the Notre Dame Cathedral in the Disney animation- "Hunch-Back of Notre Dame" but also in the "Miraculous Ladybug". During their research they found contemporary examples of famous pieces of furniture in movies or cartoons starting from the Disney production: rococo furniture in "The Aristocrats" or in "The Princess and the Frog", the psyche mirror in animations like "Beauty and the Beast", "Tangled" but also the Eames Lounge Chair \& Ottoman in the animation series "Powerpuff Girls".

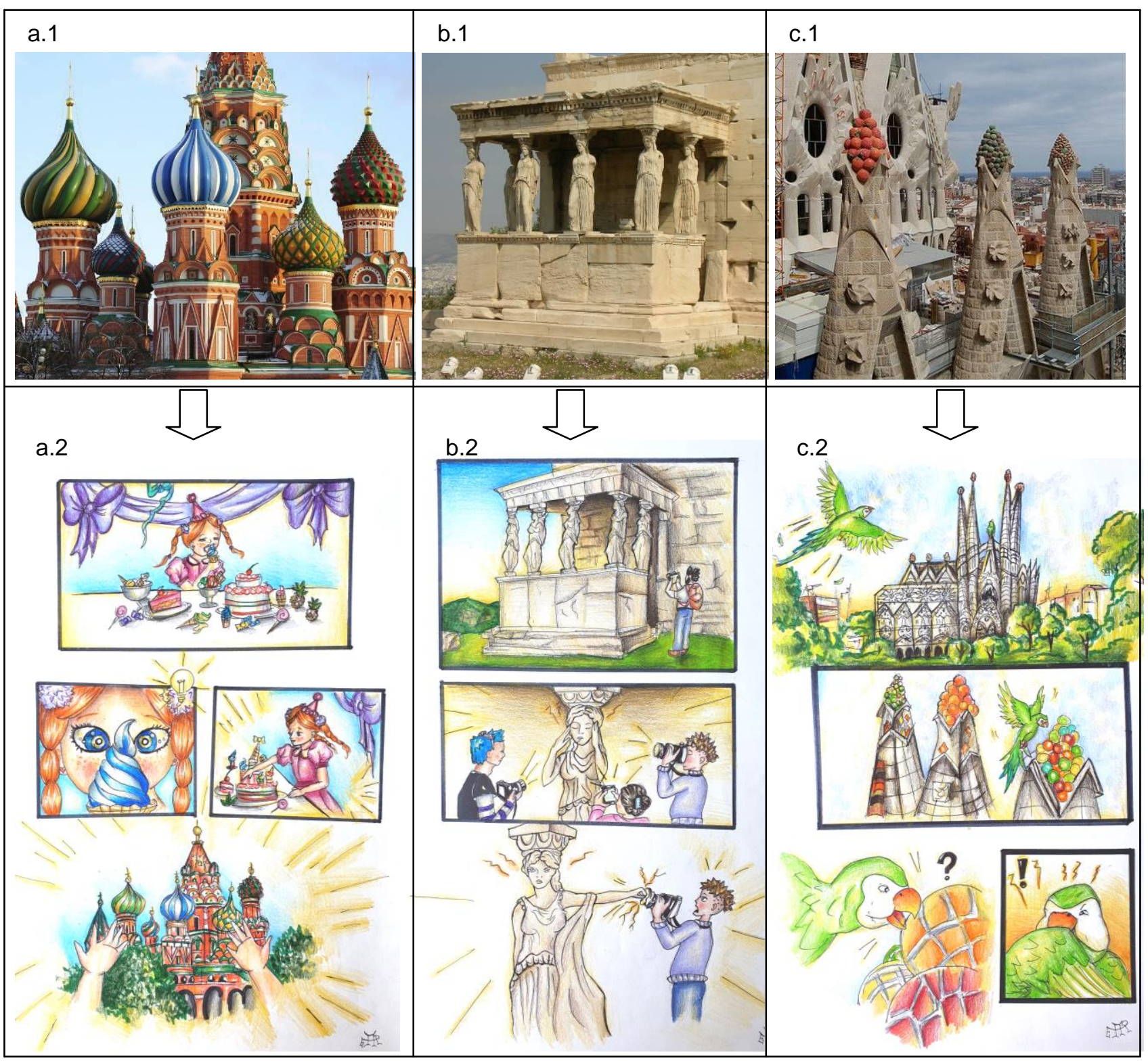

Fig. 3.Worksheets representing three iconic buildings and their reinterpretation in order to be easy to remember by children; a1) Saint Basil Cathedral in Moscow, Russia; b1)The Erechteion, Athens; c1) The cathedral Sagrada Familia designed by Antonio Gaudi, Barcelona; Online source: a1)

https://bigtimemoscow.com/top-5-greatest-churches-of-moscow/; b1)https://www.ancient.eu/image/389/theerechtheion-athens/; c1)https://www.pinterest.com/pin/105764291221649089/; a2),b2),c2) Drawings realized by Andrei Popescu, student at Politehnica University, Faculty of Architecture and Urban Planning, Furniture and Interior Design Specialization, 2019. 
The second part consisting in 10 drawing worksheets stimulates the students not only to reproduce by copy a few pieces of furniture, but also helps them to understand better the history, the origin, materiality, the ornamentation, the shape and function of the furniture and raise the problem of their use in a different context, reinterpreting and introducing it into the story of a comic strip, in order to be understandable and attractive for children. (Figure 2 and 3 a2.,b2.,c2.). In this way the chair designed by Philip Starck can move and in the story of the strip we can find the explanation of its form (Figure 2 a1 and a2). In Figure 3 we can see how the caryatids from the Erechteion on the acropolis of Athens, can move when there are getting tired from all the photo shooting sessions (Fig 3 b1 and b2) but also how a parrot is tricked to eat the ornamental fruits from the roof of Sagrada Familia Cathedral. (Fig $3 \mathrm{c} 1$ and c2). Before drawing these worksheets they had to realize a scientific documentation about the objects chosen to be the subjects of their stories.

The main objectives and results of the summer practical work and workshop were that students and children have learned and documented about different monuments of architecture and interior design by watching animation movies or analyzing comic strips; the students have acquired communication and socialization skills through creative work with and for children; it increased the interest for knowledge and personal development among children and the interest for continuing learning among university students; the students had the opportunity of systemizing their knowledge in a way that children can understand and value.

\section{CONCLUSION}

By approaching the problem of teaching history of architecture and stylistics to students we can see that using alternative methods in which they are challenged to analyze, to reinterpret the information and present the material to children in order to be understood, puts the students in the situation of realizing a scientific documentation, to create a connection between what they read or hear at the course and the real applicability of what they study. In order to be able to create a comic strip with a coherent story in order to attract children they have to assimilate in a logical way all the characteristics of the object they studied.

The media, the comic strips, the online games have an enormous influence on children and young adults intellectual development. Combining the process of learning with key elements from media will produce a better teaching system and a better understanding of the connection between theoretical information they assimilate during university courses and the real applicability of it.

\section{ACKNOWLEDGEMENTS}

Experiment realized with the help of students from the Faculty of Architecture and Urbanism, Furniture and Interior Design Specialization, Politehnica University (Andrei Popescu, Ana-Maria Hulea, Roxana Savu), during the summer school practical work in 2019 and 2020.

\section{REFERENCE LIST}

American Academy of Pediatrics, 2001, "Media Violence", Pediatrics 108:1222-1226.

Blackwell Clark, L., "History of Media for Children, General Considerations, Studies of Media Influence, Domains of Influence, Recomandations", StateUniversity.com, Online source: https://education.stateuniversity.com/pages/2212/Media-Influence-on-Children.html, Consulted in 01.01 .2021

Bonwell, J.,A., (1991), Active learning: creating excitement in the classroom, ASH-ERIC Higher Education Report, No.1, Washington, D.C., The George Washington University, School of Education and Human Development.

Bucătaru, M., (1991), Stiluri și ornamente la mobilier, Ministerul Învățământului și Știnței, Editura Didactică și Pedagogică, București.

Bussagli, M., (2005), Să înțelegem arhitectura, Enciclopedia RAO, București.

Delbene Guidoni, G., (2019), “Archi Disney- Architettura, citta, design nell'arte di Floyd Gottfredson”, ISBN: 978-88-6288-499-0, Odoya, Bologna.

Dumitrescu, C., Povian, C., Milincu, C., Tudoran, O., (2018), Stilistica de interior, Editura Eurobit Timisoara, Waldpress Timisoara. 
Eurostat- Statistic Explained, "Being Young in Europe today-digital world", July 2020, Online source: https://ec.europa.eu/eurostat/statistics-explained/index.php/Being young in Europe today digital world\#Youth online: a way of life, Consulted in 01.01.2021.

Eurostat- Statistic Explained, "Are Europeans glued to their screens?" Online source: https://ec.europa.eu/eurostat/web/products-eurostat-news/-/DDN-20180507-1, Consulted in 01.01 .2021$.

Hustn, A. C., Donnerstein, E., Fairchild, H., Feshbach, N. D., Katz, P. A., Murray, J. P., Rubinstein, E. A., Wilcox, B. L., Zuckerman, D., (1992), "Big World, Small Screen: The Role of Television in American Society", Lincoln: University of Nebraska Press.

Povian, M., C., (2020), Alternative Methods of Teaching Interior Design Stylistics, Abstracts\&Proceedings of INTCESS 2020- $7^{\text {th }}$ International Conference on Education and Social Sciences, Dubai, ISBN: 978-60582433-8-5.

Povian, M., C., (2019), "The Little Architects" workshop an active learning and teaching method for children in need, SHS Wev Conf. Volume 66, 2019, ERPA International Congress on Education 2019 (ERPA 2019) 